Article

\title{
Forecasting Electricity Market Price for End Users in EU28 until 2020-Main Factors of Influence
}

\author{
Simon Pezzutto ${ }^{1, *}$, Gianluca Grilli ${ }^{2,3}$, Stefano Zambotti ${ }^{1}$ and Stefan Dunjic ${ }^{4}$ \\ 1 Institute for Renewable Energy, European Academy of Bozen/Bolzano (EURAC Research), Viale Druso 1, \\ 39100 Bolzano, Italy; stefano.zambotti@eurac.edu \\ 2 Economic and Social Research Institute, Sir John Rogerson's Quay, Dublin Dublin 2, Ireland; \\ Gianluca.Grilli@esri.ie \\ 3 Trinity College Dublin, the University of Dublin, Dublin Dublin 2, Ireland \\ 4 Joule Assets Europe Group SRL, Via Cesare Battisti 56, 41121 Modena, Italy; sdunjic@jouleassets.com \\ * Correspondence: simon.pezzutto@eurac.edu; Tel.: +39-0471-055-622
}

Received: 13 April 2018; Accepted: 3 June 2018; Published: 5 June 2018

\begin{abstract}
The scope of the present investigation is to provide a description of final electricity prices development in the context of deregulated electricity markets in EU28, up to 2020. We introduce a new methodology to predict long-term electricity market prices consisting of two parts: (1) a self-developed form of Porter's five forces analysis (PFFA) determining that electricity markets are characterized by a fairly steady price increase. Dominant driving factors come out to be: (i) uncertainty of future electricity prices; (ii) regulatory complexity; and (iii) generation overcapacities. Similar conclusions derive from (2) a self-developed form of multiple-criteria decision analysis (MCDA). In this case, we find that the electricity market particularly depends on (i) market liberalization and (ii) the European Union (EU)'s economy growth. The applied methodologies provide a novel contribution in forecasting electricity price trends, by analyzing the sentiments, expectations, and knowledge of industry experts, through an assessment of factors influencing the market price and goals of key market participants. An extensive survey was conducted, interviewing experts all over Europe showed that the electricity market is subject to a future slight price increase.
\end{abstract}

Keywords: electricity market price; Europe; forecast; long term; Porter's five forces analysis; multiple-criteria decision analysis

\section{Introduction}

The end of 2016 marked the 20th anniversary of the first regulatory directive aimed at liberalizing the European Union's (EU's) electricity markets. Since then, electricity markets and systems throughout Member States (MS) went towards significant structural changes, incentivized by market competitiveness and by the introduction of new disruptive technologies-Renewable Energy Sources (RES), energy storage, and demand-side management. Liberalization of national electricity markets was followed in parallel by efforts to integrate these markets into a pan-European network, aiming to strengthen the security of supply, improve technical capabilities for network management, and increase pricing transparency and efficiency in both wholesale and retail markets [1-9].

Because of the aforementioned developments, market prices are now a key signal for all stakeholders. For example, traditional generators might be concerned with the high marginal costs of their plants due to fuel price increase compared to new entrants based on renewable sources, which are less affected by non-renewable resource prices. In addition, market prices are important for policy makers to balance acceptable costs for consumers and for the fulfillment of environmental policy goals.

Moreover, the restructuring of the power sector has also led to the development of wholesale markets for electricity-based financial products, which both influence the market and respond to it. 
Consequently, the ability to forecast electricity market prices is highly valuable to all market players, as it allows them to minimize their risks, increase their profits, or achieve other goals. We consider electricity prices, categorizing them into the customary distinction of short, medium, and long term. Although there is no consensus of what the time limit should be, we consider a common classification using hourly and daily prices as short-term forecast, monthly prices as medium-term, and yearly and over as long-term [10].

In the literature, there is a number of different quantitative methods focus on short-term price forecasting, addressing hourly and daily prices in day-ahead and intra-day markets, which are data-rich and therefore provide a suitable foundation for such analysis [11-36]. Among the frequently used techniques, econometric models based on time series analysis are the most common [37]. In a review of the literature, Weron identifies Auto Regressive Moving Average (ARMA)-type as reference models to account for non-stationarity in the data. An example is the influential paper by Contreras et al. (2003) [25], which proposes an Auto Regressive Integrated Moving Average (ARIMA) model to evaluate next-day prices in Spain and California. Generalized Autoregressive Conditional Heteroscedasticity (GARCH) [34,37] is another common model to estimate day-ahead prices [8], which better fits highly volatile prices compared to ARIMA. In some cases, there are hybrid models attempting to combine both ARIMA and GARCH [38]. Other commonly used methods include machine learning and artificial intelligence. More specifically, artificial neural networks [39], support vector machines [25,40-42], and also agent-based models [43]. In general, econometric models are very popular to estimate short term prices, because in this time span, the influence of external variables is low and price levels can be predicted with good precision.

Forecasting market prices trends in the medium and long term is significantly more challenging due to the increased number of factors that influence prices in these time frames-economic cycles, climate and weather conditions, geopolitical events, technological breakthroughs, demographics, etc. [44-51]. Attempting to predict long-term prices based on historical data might be misleading because of unpredicted factors affecting future development of the markets. For this reason, scientific evidence suggests focusing on predicting the demand level rather than average price, which can still give an insight on future prices [52,53] or on future density of the demand to identify peaks [54]. It is also common to study factors affecting energy planning rather than price levels [55]. These features of the energy sector suggest that some prior information on the variables affecting prices is of utmost importance to understand the directions of energy markets. The ability to predict market forces is beneficial to foresee energy market prices in the long term, which are of importance to energy producers and retailers as well as energy service companies for strategic planning and considerations of future capacity-investments in generation and transmission assets.

In the attempt to tackle the important issue of energy planning in the medium to long term, we propose a methodology allowing the exploratory analysis of the forces affecting the future electricity price in Europe. Our research focuses on the following questions:

- What future development of electricity prices for final users can be expected at EU28 level in the long term (up to 2020)?

- Can you assign a relative importance to the factors influencing the price?

- What are the implications of the expected price forecast?

To answer these questions we apply a two-step methodology based on (i) a Porter's five forces analysis (PFFA) and on (ii) a multiple-criteria decision analysis (MCDA) to data collected with personal interviews to European experts in energy and electricity markets. The first step (PFFA) identifies the relevant forces affecting the European electricity markets. The PFFA is a useful model for analyzing the attractiveness and competitiveness in an industry. In our case, we use a novel, modified version of the PFFA to assess the impact of market forces and factors on the end-user electricity price. The second (MCDA) concentrates on the specific goals of key market players, as well as factors leading to 
the achievement of these goals. Both these approaches—a quantitative and a qualitative one-generate the same result as output: a slight growth of end users' electricity price.

The approaches used in this paper provide an innovative way of forecasting long term electricity market prices, through the use of the modified PFFA and the MCDA as the tools for assessing the knowledge of leading industry experts. The novel aspect of our piece of research is the bottom-up approach carried out by means of interviews to experts of energy markets at European level, as it is important to understand sentiments and expectations of specialists in the field of investigation. Following this approach, we are able to use the expert's knowledge to identify the driving factors which affect the market, and, directly or indirectly, the price of electricity. We specifically focus on end users with low bargaining power in the market, such as households and small service sector units like offices, shops, restaurants, and bars, excluding bulk purchasers like industries, wholesale and retail, as well as large commercial, etc.

The rest of the paper is organized as follows. Section 2 contains materials and methodology utilized. Section 3 contains the results. Section 4 contains the discussion and conclusions.

\section{Materials and Methods}

\subsection{Porter's Five Forces Analysis}

Here we apply a PFFA to provide a clear outlook of end users electricity prices market. The PFFA is traditionally used to gauge the level of competitiveness and therefore possible profitability in a given industry [56]. In this paper, we use a modified version of the PFFA to measure the impact of the four market forces on the end user electricity price. We restrict our research to end users only, due to the high complexity of the market investigated. End users prices are affected by three main components. A first factor is the cost of energy, which is sensitive to the degree of competition in the market, fuel prices, and technology. A second component of the end user prices is the regulated costs (i.e., transmission and distribution), while the last component is taxation. While it is difficult to predict taxes at country level, our analysis concentrates on the first two components, because market forces might directly affect producers business and therefore their own cash flows. The PFFA model indicates the status quo of a market and predicts its future given a starting point [57]. The tool employs the de facto framework of a market [58]. We use a model based on Pezzutto et al. [59] that goes beyond a traditional PFFA. This model offers a more transparent evaluation of single forces based on a grading scheme and an associated weighting scale which are completed by a novel calculation system.

The PFFA model is based on a five-forces analysis of a market:

Force 1 Threat of new entrants

Force 2 Threat of substitute products or services

Force 3 Bargaining power of suppliers

Force 4 Bargaining power of buyers

Force 5 Overall result.

The forces are defined by their respective factors whose influence on the market and importance are specified as positive: ' + ' price increases, or negative: ' - ' price decreases, and ranging from $10+$ to $10-$, with 0 indicating no influence, respectively.

Forces 1 to 4 where analyzed summing their individual factors. For example, let us say there are 6 factors influencing Force 1, with respective values of $1+2+3+4+5+$ and $6+$. The strength of Force 1 is determined by summing up the values of the factors influencing it-in this example, Force 1 is equal to $21+$. In contrast to a traditional PFFA, Force 5 does not indicate the rivalry among existing competitors, but an overall result concerning the future growth or diminishing of the future electricity price in Europe. Force 5 was determined as a sum of the values for Forces $1-4$. Force 5 is determined by an evaluation scale obtained summing up the number of factors that quantify Forces 1 to 4 , multiplied by $10+$ and $10-$ (representing upper and lower boundaries. For example, if there are 10 factors overall 
influencing Forces 1-4, and each factor is expressed on a scale of $10+$ to $10-$, the evaluation scale for Force 5 will be between 100+ and 100-. The resulting Force 5 was then translated into percentage form by dividing it by the boundaries of the corresponding evaluation scale. The scale itself is then translated into percentages: $100 \%+$ and $100 \%-$. The PFFA scheme is visualized in Figure 1.

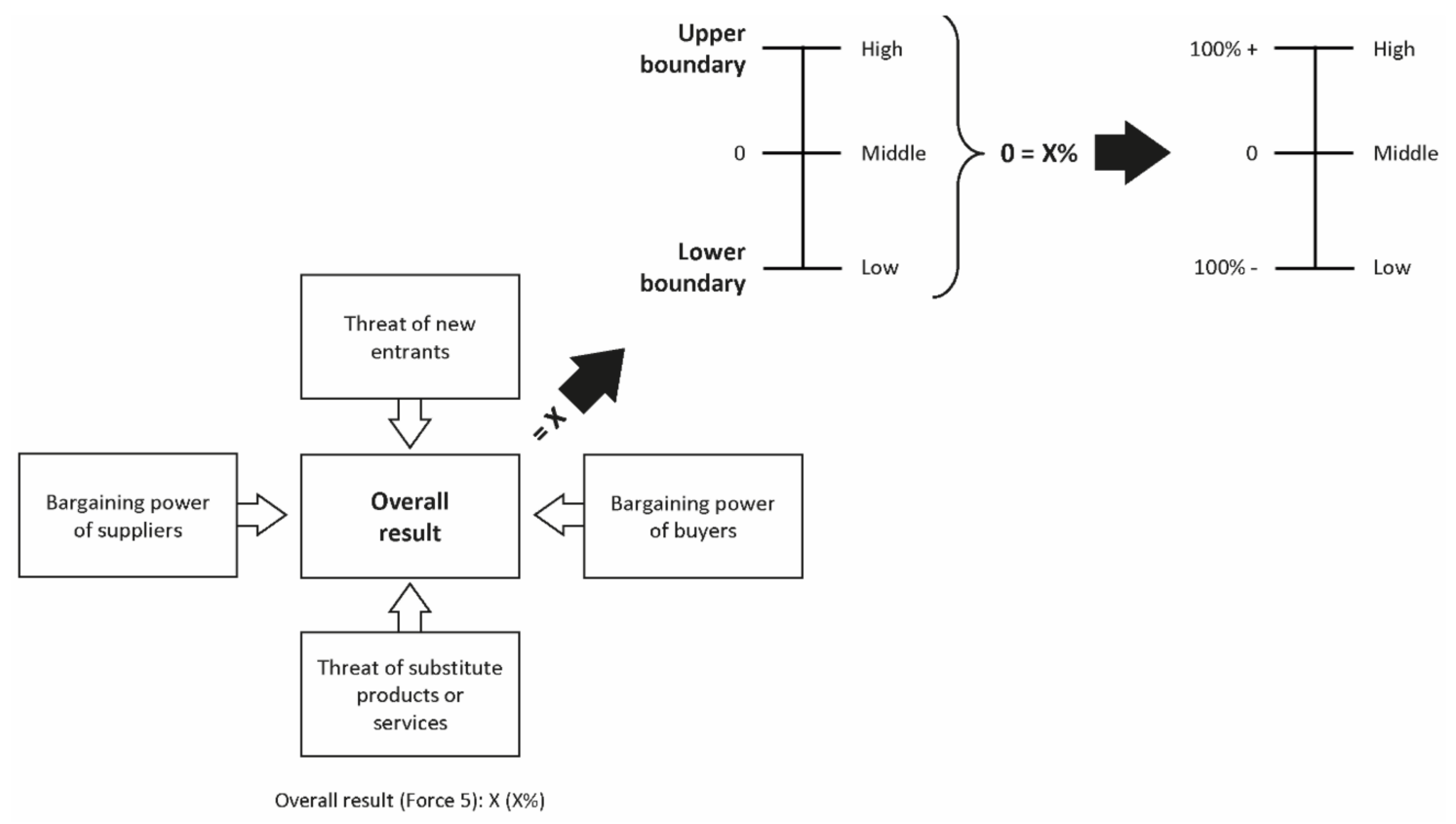

Figure 1. Porter's five forces analysis diagram [58].

The enhanced PFFA was used to study the current prices market of all 28 EU MS. We carried out a survey to extract the factors influencing the forces listed above and on this basis we analyzed the market. We handed out a questionnaire and carried out a phone survey to market experts involving 28 interviewees: one expert per MS. We then implemented a consistency analysis to determine how many experts agreed on the importance of a given factor. We quantify the agreement level by means of the interquartile range (IQR) of the weights distribution [60-62]. IQR defines the variation between the 75th percentile and the 25th percentile of the input data. In turn, the 75th percentile identifies the weight under which we find $75 \%$ of the weights per goal or per factor. Therefore, a high IQR corresponds to a low agreement level among experts [63].

\subsection{Multiple-Criteria Decision Analysis}

In order to obtain reliable future development predictions for the electricity prices market, we applied a sort of MCDA based on Pezzutto et al. [59]. The MCDA, involving multiple conflicting criteria, is a suitable tool to generate forecasts [64-68]. This tool accounts for both the market's participants' goals and the external factors characterizing market development. The goals and factors' importance were weighted by interviewees. Once again, we selected 28 interviewees, each representing an EU Member State. All the experts differ from the previous PFFA. Based on their importance and influence (positive: ' + ' price increases, or negative: ' - ' price decreases) on the markets' price, single goals' and factors' weights range, in turn, from 10+ to 10-. As was the case for the PFFA, 1 indicates minimally importance, 10 highest importance, and 0 no importance.

Again, sign ' + ' stands for positive and ' - ' for negative influence. The applied tool followed this method: weighted goals and factors were ordered vertically and horizontally, respectively, forming the borders of a matrix. We then specify the influence of each factor relative to each goal. Thus, we measure the influence of the external factors on the respective market participant goals multiplying the factors' weights by the related goals' weights. We assign the following sign multiplication rule: 
a negative number multiplied by a positive one, yields a negative sign; the multiplication of two negative numbers still yields a negative sign. Next, summing up the resulting terms we obtain a number per factor which indicates the measured influence and importance of the factor on the market participants' goals. Then, the factors' outcomes are marked by an evaluation scale (ranging from low to middle and high). We identify the upper bound of the evaluation scale by squaring the highest weight (value: 10) and multiplying its outcome by the number of goals (upper boundary marked by ' + ' and lower boundary by ' - '). Finally, we analyze outcome indications comparing the measured influence to the importance of the external factors on the market participant goals. The core of the calculation allows to evaluate the relevance of single external factors on market participants' goals to subjectively deliver predictions for possible future market developments. As such, the performed investigation is not objective and limits to the assessment of external factors influencing the key market participants in reaching their goals. Figure 2 visualizes the MCDA calculation scheme.

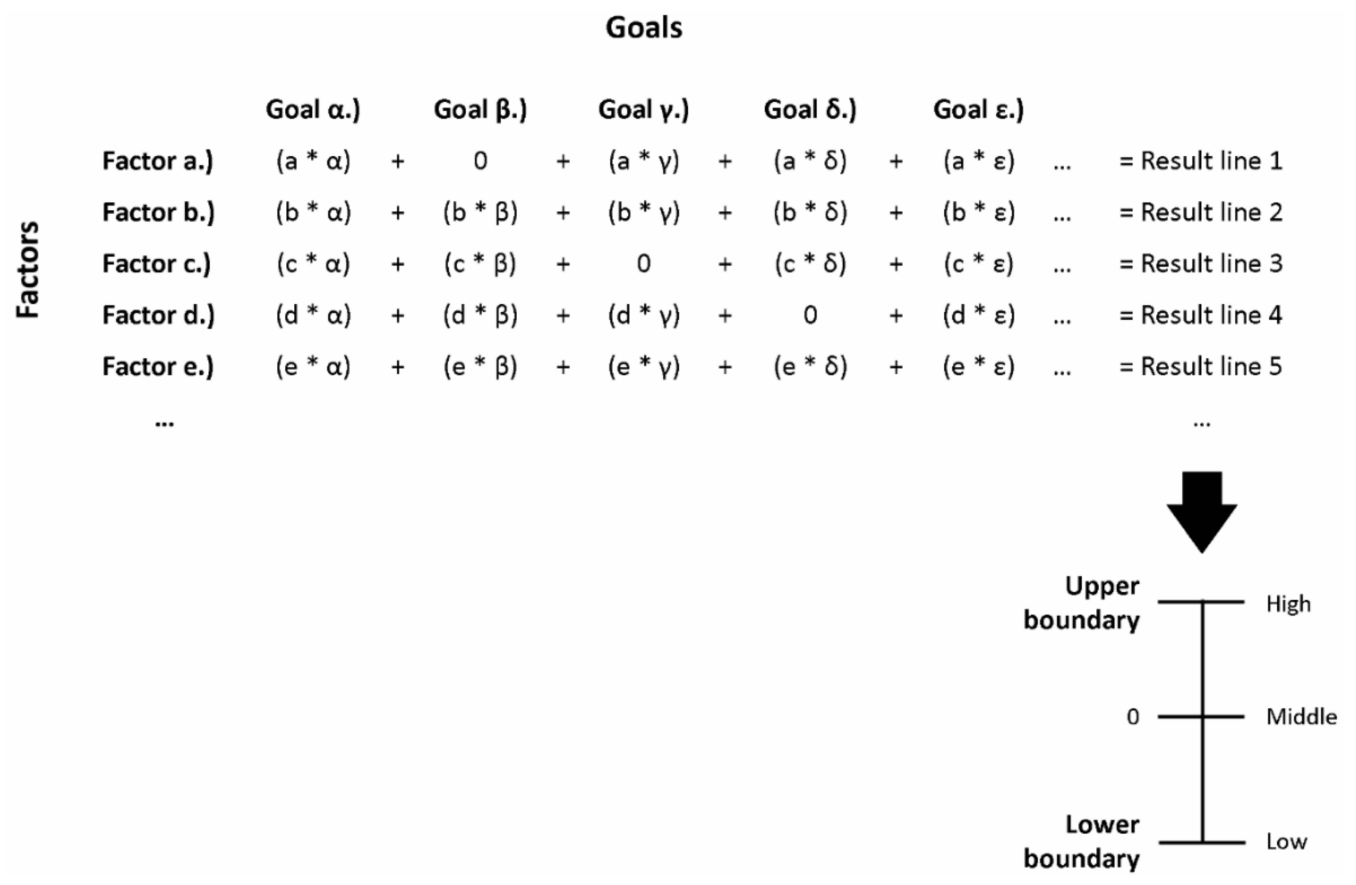

Figure 2. Multiple-criteria decision analysis scheme [58].

We compared the results per factor to provide indications regarding the investigation's result.

Afterwards, we implemented a consistency check to understand the agreement level among experts concerning the importance of the goals and factors. Similar to the PFFA, the IQR of the weights distribution was once more utilized for quantifying the agreement level among experts [63].

Concerning the selection of market participants, goals, and factors, pertinent for the future development of the investigated market, experts' declarations were considered. Only market participants, goals, and factors considered as relevant by more than $50 \%$ of the experts interviewed have been utilized for the present investigation. In the majority of cases, information provided coincide and justifications to support choices were given.

Like in the PFFA, we adopted the following goals and factors' evaluations (simple mean calculation) from the weights indicated by the experts interviewed (see Tables A1-A6) for PFFA and MCDA respectively). Experts' weights per goal and factor were averaged and rounded obtaining full numbers. We obtained all following goals and factors' features from the declarations provided by experts and counterchecked them with the scientific literature.

Experts' indications were summed up while eliminating all unproven information. For both applied methods (PFFA and MCDA), per factor and goal, experts attributed either ' + ' or ' - ' signs only. 
Figures 3 and 4 recapitulate various steps of methodology applied (Figure 3 for PFFA and Figure 4 for MCDA).

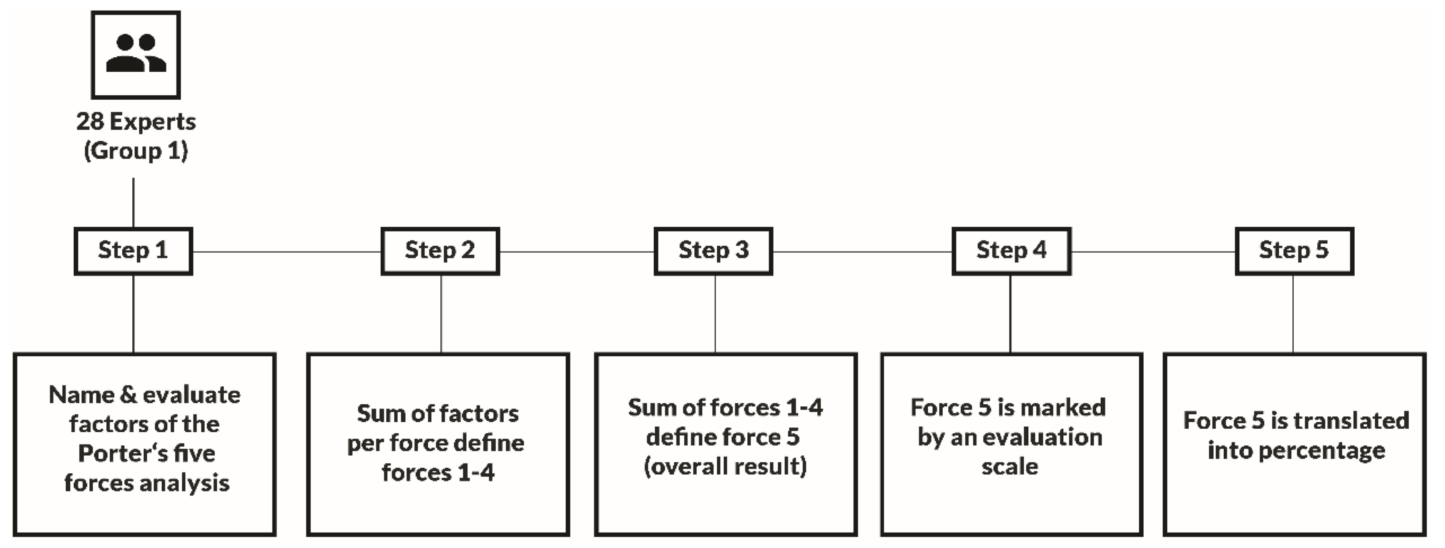

Figure 3. Summary of various steps for methodology applied (Porters' five forces analysis).

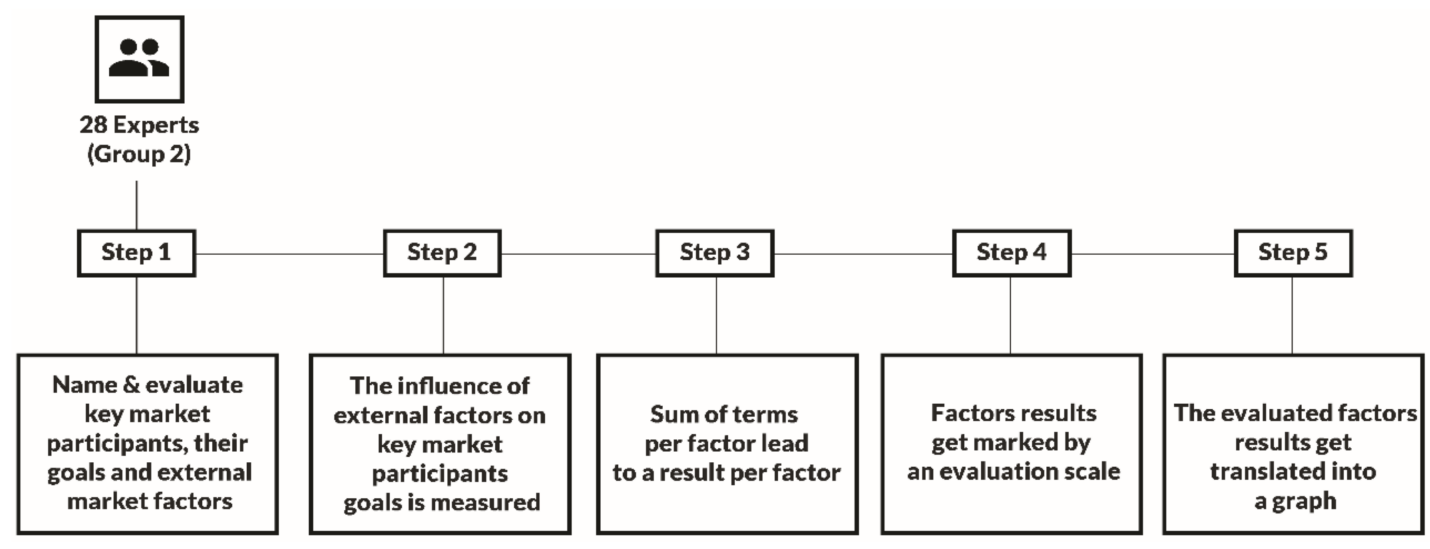

Figure 4. Summary of various steps for methodology applied (Multiple-criteria decision analysis).

\section{Results}

\subsection{Porter's Five Forces Analysis}

Table 1 shows an overview of factors with respective importance and influence regarding the PFFA mentioned by experts. Please see Tables A1-A3 (Appendix A) for all experts' indications.

Like visible in Table 1, the highest number of mentioned factors relate to the Threat of new entrants. This category includes the absolute majority of positive points. Here, all issues are marked by a ' + ' sign. The latter-mentioned force is also characterized by the highest amount of points-nearly double than other forces. Hence, the threat of new entrants comes out to be the force with the highest positive influence on the investigated market. Most of the negatively marked factors are to find within the forces Bargaining power of buyers and Threat of substitute products or services. These two sections are marked by negative points solely. Force 3 comes out to be mixed with both plus and minus signs.

Table 2 highlights the performed factors' evaluations obtained by interviewing experts. Calculations concerning Force 5 lead to a value of $7+$ over a maximum of 150 units (15 factors). This outcome is equal to a $5 \%+$ (maximum: $100 \%+$ ), thus yielding a slightly positive overall result. A number of experts stated that the uncertainty of future electricity prices, regulatory complexity, and generation overcapacities are the driving factors of the analyzed market. 
Table 1. Porter's five forces analysis factors with respective importance and influence concerning the electricity market price in the European Union.

\begin{tabular}{|c|c|}
\hline Force 1 Threat of New Entrants & Force 2 Treat of Substitute Products or Services \\
\hline $\begin{array}{ll}\text { 1. } & \text { Uncertainty of future electricity prices: } 8+ \\
\text { 2. } & \text { Public acceptance: } 7+ \\
\text { 3. } & \text { Regulatory complexity: } 8+ \\
\text { 4. } & \text { Environmental licenses: } 7+ \\
\text { 5. } & \text { Generation overcapacities: } 8+ \\
\text { 6. } & \text { Grid connection: } 7+\end{array}$ & $\begin{array}{l}\text { Utilization of fossil fuels driven devices: } 1- \\
\text { Energy efficiency improvements: } 5- \\
\text { Rational use of energy: } 4-\end{array}$ \\
\hline Force 3 Bargaining Power of Suppliers & Force 4 Bargaining Power of Buyers \\
\hline $\begin{array}{l}\text { 1. Amount of competitors: } 7- \\
\text { 2. Market liberalization: } 7- \\
\text { 3. } \quad \text { Capital accessibility for new investments: 7+ }\end{array}$ & $\begin{array}{l}\text { 1. Freedom in choosing supplier: 7- } \\
\text { 2. Accessibility to information: 7- } \\
\text { 3. Easiness to switch supplier: 7- }\end{array}$ \\
\hline
\end{tabular}

Table 2. Evaluation of the treated factors and related calculations, Porter's five forces analysis for the electricity market price, EU28 ( \pm units).

\begin{tabular}{llcc}
\hline \multicolumn{1}{c}{ Forces } & Factors' Evaluations & Results $(\Sigma)$ & $\begin{array}{c}\text { Evaluation Scale's } \\
\text { Range ( } \pm \text { ) }\end{array}$ \\
\hline Force 1-Threat of new entrants & & $45+$ & \\
Force 2-Threat of substitute products or services & $8+7+8+7+8+7+$ & $10-$ & \\
Force 3-Bargaining power of suppliers & $1-5-4-$ & $7-$ & \\
Force 4-Bargaining power of buyers & $7-7-7+$ & $21-$ & 150 \\
Force 5-Overall result & $7-7-7-$ & $7+$ & $100 \% \pm$ \\
Force 5-Overall result (\%) & & $5 \% \pm$ & \\
\hline
\end{tabular}

Like already mentioned before, we utilized a consistency check to quantify how much experts agreed on the importance of the factors. For the present case, each IQR per factor is less than three, which is relatively low. Thus, we assume a certain consistency among expert weights. Tables A1-A3 (Appendix A) provides further information on interviewees' responses.

\subsection{Multiple-Criteria Decision Analysis}

In the present market investigation, legislators, market regulators, electricity providers, and customers are identified as most relevant market players. Two of the key market players follow specific goals: profit maximization (max.) for the electricity provider, and cost minimization for the customers. The regulators and legislators are considered neutral players.

Legislators: policy and legislative instruments will significantly influence the electricity price to come. The EU is attempting to harmonize the wholesale markets at European level, for example through the Euphemia and Cosmos algorithms, computing optimization problems to harmonize prices [61,62]. However, at the moment electricity markets are especially regulated at national level $[59,60]$. Environmental policies play a crucial role, which include among others, environmental impact reductions (in particular the European Trading System-EU ETS) [69] and the utilization of energy coming from RES (especially the EU 2020 goals [70]). Thus, the European electricity market is characterized by a number of respective EU directives and regulations (in particular the Electricity Directive and related regulations [71]).

Market regulators: such as relevant competent administrative bodies and agencies in particular guaranty, among other points, that costumers can change electricity supplier.

Electricity provider: the future electricity market is characterized by the electricity producers' aspiration to maximize their income. Profitability means the ability to acquire earnings above expenses and other costs during a specific period [72]. As by the interviewees, this section includes also 
transmission system operators (TSOs) and distribution system operators (DSOs). These stakeholders are often owned by electricity producers and have the same goal.

Customers: the future electricity market is influenced by the electricity costumers' interest to purchase energy with the best cost-benefit ratio (benefit to cost max.) [73-75].

Tables 3 and 4 display the goals and factors with respective influence and importance indicated by interviewees. Please see Tables A4-A6 (Appendix A) for all experts' indications.

Table 3. Goals of the future electricity market key players in Europe.

\begin{tabular}{ccccc}
\hline & \multicolumn{4}{c}{ Goals } \\
\hline \multirow{2}{*}{ Field } & Legislation & Regulation & \multicolumn{2}{c}{ Profitability } \\
\hline \multirow{2}{*}{ Goals } & Environmental policies & Feasibility in changing supplier & Income max. & Benefit to cost max. \\
\cline { 2 - 5 } & $8+$ & $4-$ & $8+$ & $3-$ \\
\hline
\end{tabular}

Table 4. External factors having an influence on the future electricity market evolution.

\begin{tabular}{cccc}
\hline \multirow{2}{*}{ Evaluation } & \multicolumn{3}{c}{ Factors } \\
\cline { 2 - 4 } & Renewable energy production & Fossil fuels' price & Extreme weather events \\
\hline & $\begin{array}{c}\text { Social unacceptance of higher electricity } \\
\text { prices due to incentives/subsidies }\end{array}$ & $\begin{array}{c}\text { Electricity market } \\
\text { concentration }\end{array}$ & $1-$ \\
\cline { 2 - 4 } & $1-$ & $5+$ & $1+$ \\
\hline & Electricity market liberalization & EU economy growth \\
\cline { 2 - 4 } & $6-$ & $4+$ \\
\hline
\end{tabular}

The goals highly ranked with regard to their importance result to be income maximization and Environmental policies. Feasibility in changing supplier comes out to be about half that important and the Benefit to cost maximization is last ranked.

The factors influencing the key market players' goals show following order with regard to their importance: the Liberalization of EU's electricity market is first, shortly behind we find Concentration of EU's electricity market, followed by Renewable energy (RE) production and Europe's economy growth. Fossil fuels' price comes next with approximately half of the first ranked factor.

Extreme weather events, Social unacceptance of higher electricity prices due to incentives/subsidies, and E-mobility result to be only of limited importance.

Table 5 shows which factors influence which goals (cells marked with an " $X$ " show a relation among respective factors and goals, and cells filled with "0" show no relation).

Table 5. External factors and market participants' goals of the future electricity market. (EU28).

\begin{tabular}{cccc}
\hline & Goals & & \\
\hline Factors & $\begin{array}{c}\text { Environmental } \\
\text { Policies }\end{array}$ & $\begin{array}{c}\text { Feasibility in } \\
\text { Changing Supplier }\end{array}$ & $\begin{array}{c}\text { Income Max. } \\
\text { Benefit to } \\
\text { Cost Max. }\end{array}$ \\
\hline Renewable energy production & $X$ & 0 & 0 \\
\hline Fossil fuels' price & $X$ & 0 & 0 \\
\hline Extreme weather events & $X$ & 0 & 0 \\
\hline $\begin{array}{c}\text { Social unacceptance of higher electricity } \\
\text { prices due to incentives/subsidies }\end{array}$ & $X$ & 0 & $X$ \\
\hline Electricity market concentration & 0 & $X$ & $X$ \\
\hline E-mobility & $X$ & 0 & $X$ \\
\hline Electricity Market liberalization & 0 & $X$ & $X$ \\
\hline EU economy growth & 0 & 0 & $X$ \\
\hline
\end{tabular}


The factor influencing most key market players' goals comes out to be Concentration of EU's electricity market. Fossil fuels' price, Extreme weather events, Social unacceptance of higher electricity prices due to incentives/subsidies, and E-mobility influence half of the goals identified. Finally, EU's electricity market liberalization and EU's economy growth affect solely one goal.

Table 6 recapitulates the carried out goals, factors, and respective items' evaluations and displays the calculations, which lead to the overall result regarding the investigated market forecast.

Table 6. Results calculation for the multiple-criteria decision analysis: influence of the external factors on the goals of the most relevant market participants.

\begin{tabular}{|c|c|c|c|c|c|}
\hline \multirow[b]{2}{*}{ Factors } & \multicolumn{4}{|c|}{ Goals } & \multirow[b]{2}{*}{ Results } \\
\hline & $\begin{array}{l}\text { Environmental } \\
\text { Policies }(8+)\end{array}$ & $\begin{array}{c}\text { Feasibility in Changing } \\
\text { Supplier }(4-)\end{array}$ & Income Max. (8+) & $\begin{array}{l}\text { Benefit to Cost } \\
\text { Max. (3-) }\end{array}$ & \\
\hline $\begin{array}{l}\text { Renewable energy } \\
\text { production }(4+)\end{array}$ & $(4+) \times(8+)=32+$ & - & - & $(4+) \times(3-)=12-$ & $(24+)+(9-)=20+$ \\
\hline Fossil fuels' price (3+) & $(3+) \times(8+)=24+$ & - & & $(3+) \times(3-)=9-$ & $(16+)+(6-)=15+$ \\
\hline Extreme weather events (1-) & $(1-) \times(8+)=8-$ & - & $(1-) \times(8+)=8-$ & - & $(8-)+(8-)=16-$ \\
\hline $\begin{array}{l}\text { Social unacceptance of } \\
\text { higher electricity prices due } \\
\text { to incentives/subsidies (1-) }\end{array}$ & $(1-) \times(8+)=8-$ & - & $(1-) \times(8+)=8-$ & - & $(8-)+(8-)=16-$ \\
\hline Market concentration (5+) & - & $(5+) \times(4-)=20-$ & $(5+) \times(8+)=40+$ & $(5+) \times(3-)=15-$ & $\begin{array}{c}(20-)+(40+)+ \\
(15-)=5+\end{array}$ \\
\hline E-mobility (1+) & $(1+) \times(8+)=8+$ & - & $(1+) \times(8+)=8+$ & $(1+) \times(3-)=3-$ & $\begin{array}{c}(8+)+(8+)+(3-)= \\
13+\end{array}$ \\
\hline Market liberalization (5-) & $(5-) \times(8+)=40-$ & $(5-) \times(4-)=20-$ & $(5-) \times(8+)=40-$ & - & $\begin{array}{l}(40-)+(20-)+ \\
(40-)=100-\end{array}$ \\
\hline EU economy growth $(4+)$ & $(4+) \times(8+)=32+$ & - & $(4+) \times(8+)=32+$ & - & $(32+)+(32+)=64+$ \\
\hline
\end{tabular}

The RE production, influencing Environmental policies and Benefit to cost maximization, shows a quite strong positive influence on the electricity market price evolution. The same applies to Fossil fuels' price, with a slightly weaker influence. Extreme weather events affect rather strong Environmental policies and Income maximization. The negative influence derives from a number of interviewees' statements indicating Extreme weather events to especially damage RES and thus also the Income maximization goal. Social unacceptance of higher electricity prices due to incentives/subsidies influences the same goals and has the same influence type and importance. EU's electricity market concentration affects all identified key market players' goals, with the exception of Environmental policies. It's positive influence on the future electricity price comes out to be just minor, being affected by two negatively marked goals.

E-mobility has an influence on all goals besides Feasibility in changing supplier. Its overall positive impact on future electricity prices results to be rather strong. The EU's electricity market liberalization, influencing Environmental policies, Feasibility in changing supplier, and Income maximization, shows a heavily negative influence on the electricity price market evolution. So the EU's economy growth does, with the difference that the influence on the future electricity price is heavily positive.

To conclude, Figure 5 restates the performed goals and factors evaluations and calculations, which lead to the overall outcome regarding the investigated market forecast.

As visible in Figure 5, three factors (Extreme weather events, Social unacceptance of higher electricity prices due to incentives/subsidies, and market liberalization) indicate a negative influence on the future electricity price evolution. Two of these-Extreme weather events and Social unacceptance of higher electricity prices due to incentives/subsidies-are characterized by a solely minor impact. The largest influence on future declining prices is expected to be caused by the market liberalization. Reasons are, like indicated by experts, that extreme weather events are constantly growing but are not yet massively present so far $[57,76]$, and the same is expected to hold throughout the time frame up to 2020. Moreover, the social acceptance of higher electricity prices due to incentives/subsidies is weakened by the EU end users' low bargaining power in conditioning future electricity prices, most interviewees said. In contrast, market liberalization shows a strong negative influence on the future 
electricity price. This complies with the economic theory stating that as barriers decline the market becomes more competitive and prices fall. In fact, deregulated electricity markets encourage energy providers to compete between each other and thus set electricity price as an ordinary parameter to characterize an electricity market [1].

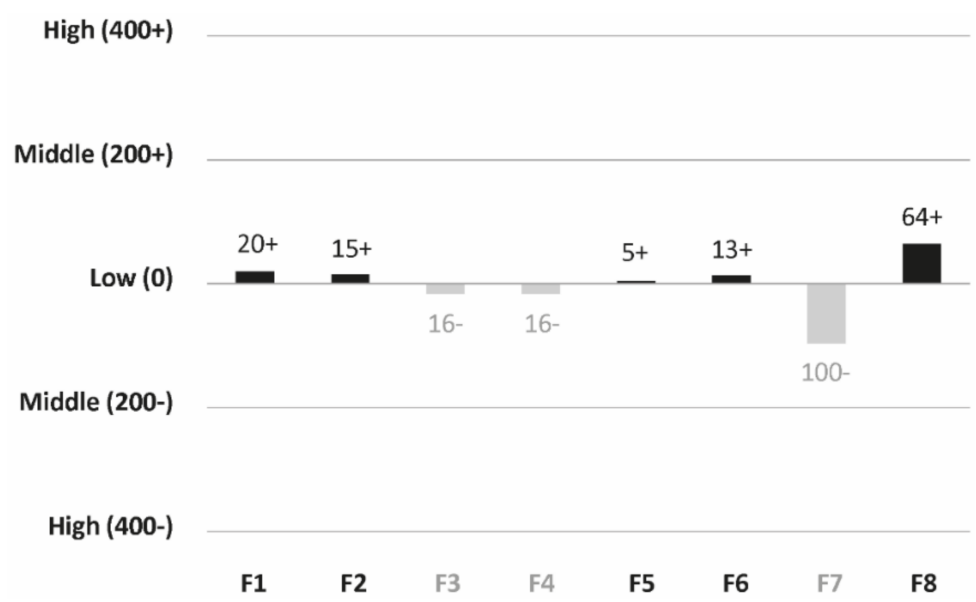

Figure 5. Results of the multiple-criteria decision analysis calculations: influence of the external factors on the goals of the most relevant market players (external factors characterized by a positive influence are over the low line and external factors characterized by a negative influence are under the low line) (F1: Renewable energy production; F2: Fossil fuels' price; F3: Extreme weather events; F4: Social unacceptance of higher electricity prices due to incentives/subsidies; F5: Market concentration; F6: E-mobility; F7: Market liberalization; F8: EU economy growth).

Furthermore, there are four factors (RE production, Fossil fuels' price, E-mobility, and EU economy growth) showing a positive influence on future electricity prices development. RE production, Fossil fuels' price, and E-mobility have a minor impact. Reasons are, as stated by experts, that incentives/subsidies for RE production, end users pay with their bills, make only a limited amount of the overall sum to settle [57]. Next, fossil fuels' price increase leads automatically to an increase in electricity price rise since almost $50 \%$ of electricity derives from fossils in Europe, even though the trend inverted in past decades [77]. Finally, interviewees stated the constant growth of e-mobility but not to expect a massive presence within 2020. In contrast, recent EU's economic growth, expected to last until 2020 and further, shows a heavily positive influence on the future electricity price development. Taking into consideration the aforementioned indications concerning Figure 4, once more the EU electricity market prices appear to be characterized by a slightly future growth. Five out of the eight considered forces indicate electricity market prices growth. Counter positioning the factors leading to increase/decrease a nearly equalization emerges.

We implement again a consistency analysis to find out how much interviewees agreed on the importance of the goals and factors. The emerging IQRs per goal and factor are available in Tables A4-A6. Not even one IQR per goal or factor results higher than a value of two, which is rather low. Hence, again, we see a certain consistency among experts' weights.

\section{Discussion and Conclusions}

The electricity market liberalization across European Union Member States started more than two decades ago. Deregulated electricity markets encourage energy providers to compete. Electricity price is an ordinary parameter of electricity markets. Market prices are now a key signal for all key market players - from traditional generators concerned with the high marginal costs of their plants compared to new entrants, to policy makers balancing between acceptable costs for consumers and the 
fulfillment of environmental policy goals. Consequently, the ability to forecast electricity market prices is highly valuable.

Porter's five forces analysis indicates that the evolution of the European Union electricity market for end users is slightly positive. Considering the electricity prices' increase by almost $30 \%$ in the last ten years, the economic models' findings-indicating a moderate growth up to 2020-appear to be trustworthy [59]. Moreover, a number of further scientific literature indications agree with our present investigation [78-80]. Porter's five forces analysis indicates that uncertainty of future electricity prices, regulatory complexity, and generation overcapacities are the driving factors of the forthcoming rise of European electricity prices.

An electricity market outlook, provided by a sort of multiple-criteria decision analysis, also indicates a slightly positive development and a strong dependence on market liberalization and on the recent European Union's economic growth.

Thus, both economic approaches applied—quantitative and qualitative-lead practically to an equal result.

It has to be underlined that within our study, there is no one country-specific multiple-criteria decision as well as Porters' five forces analysis, indicating that future electricity market prices will decrease within 2020.

As already mentioned in "Material and Methods", all key market players' goals and factors result from the declarations given by experts and counterchecked by scientific literature. Experts' answers have been summed up eliminating unproven information. This procedure led to the exclusion of almost half of the factors mentioned by experts.

The present investigation processes many responses of experts from all the Member States and normalizes their answers in a systematic way to identify what is their aggregated perception of the main factors determining the future electricity price.

It would be interesting to analyze also the development of future electricity prices for bulk purchaser (i.e., industry, large commercial, wholesale and retail, etc.), characterized be a huge bargaining power.

Author Contributions: S.P. carried out the interviews, performed the calculations, and was involved in the writing phase of the entire paper. S.D., G.G. and S.Z. provided contacts for the interviews, reviewed the manuscript, and added various specifications.

Acknowledgments: We are thankful to the Horizon 2020 Hotmaps Project (Grant Agreement number 723677), which provided the funding to carry out the present investigation. Our gratitude goes to Petra Scudo (EURAC research), who edited the entire text of the present investigation. We would like to thank Amy Segata (EURAC research) for designing the graphs of this study. Finally, we would like to convey our deepest appreciation to all interviewees for their time and patience in carrying out the surveys, making this work possible.

Conflicts of Interest: The authors declare no conflict of interest.

\section{Appendix A}

Table A1. Consistency check of the experts' answers, Porters' five forces analysis-interquartile range calculation (last line), empty cells (-) define no answers given.

\begin{tabular}{cccccc}
\hline \multirow{2}{*}{ Questionnaires } & \multicolumn{5}{c}{ Factors-P5FA } \\
\cline { 2 - 6 } & $\begin{array}{c}\text { Uncertainty of Future } \\
\text { Electricity Prices }\end{array}$ & $\begin{array}{c}\text { Public } \\
\text { Acceptance }\end{array}$ & $\begin{array}{c}\text { Regulatory } \\
\text { Complexity }\end{array}$ & $\begin{array}{c}\text { Environmental } \\
\text { Licenses }\end{array}$ & $\begin{array}{c}\text { Generation } \\
\text { Overcapacities }\end{array}$ \\
\hline 1 & $8+$ & $9+$ & $8+$ & $9+$ & $8+$ \\
2 & $9+$ & $7+$ & $9+$ & $5+$ & - \\
3 & $9+$ & $7+$ & - & $7+$ & $9+$ \\
4 & $8+$ & $5+$ & $8+$ & $7+$ & $8+$ \\
5 & $9+$ & $7+$ & $9+$ & $8+$ & $8+$ \\
6 & $8+$ & - & $8+$ & $10+$ & $8+$ \\
7 & $9+$ & - & $9+$ & $4+$ & $9+$ \\
8 & $9+$ & - & $9+$ & $7+$ & $8+$ \\
\hline
\end{tabular}


Table A1. Cont.

\begin{tabular}{|c|c|c|c|c|c|}
\hline \multirow[b]{2}{*}{ Questionnaires } & \multicolumn{5}{|c|}{ Factors-P5FA } \\
\hline & $\begin{array}{l}\text { Uncertainty of Future } \\
\text { Electricity Prices }\end{array}$ & $\begin{array}{c}\text { Public } \\
\text { Acceptance }\end{array}$ & $\begin{array}{l}\text { Regulatory } \\
\text { Complexity }\end{array}$ & $\begin{array}{l}\text { Environmental } \\
\text { Licenses }\end{array}$ & $\begin{array}{c}\text { Generation } \\
\text { Overcapacities }\end{array}$ \\
\hline 9 & $8+$ & $7+$ & $9+$ & - & $6+$ \\
\hline 10 & $6+$ & $7+$ & $7+$ & $6+$ & $6+$ \\
\hline 11 & $8+$ & $9+$ & $7+$ & $6+$ & $6+$ \\
\hline 12 & $9+$ & $7+$ & $8+$ & $6+$ & $9+$ \\
\hline 13 & - & $7+$ & $9+$ & - & $9+$ \\
\hline 14 & $8+$ & $5+$ & $8+$ & $5+$ & $6+$ \\
\hline 15 & $9+$ & $7+$ & $8+$ & $6+$ & $6+$ \\
\hline 16 & $8+$ & - & $9+$ & $7+$ & $8+$ \\
\hline 17 & $9+$ & $8+$ & $8+$ & $6+$ & $8+$ \\
\hline 18 & $9+$ & - & $9+$ & $8+$ & $10+$ \\
\hline 19 & $8+$ & $7+$ & $7+$ & $8+$ & $8+$ \\
\hline 20 & $6+$ & - & $7+$ & $6+$ & $8+$ \\
\hline 21 & $8+$ & $9+$ & $8+$ & $7+$ & $6+$ \\
\hline 22 & $9+$ & $7+$ & $9+$ & $5+$ & $8+$ \\
\hline 23 & $9+$ & $7+$ & - & $8+$ & - \\
\hline 24 & $9+$ & $5+$ & $8+$ & $6+$ & - \\
\hline 25 & $8+$ & $7+$ & $9+$ & $7+$ & $9+$ \\
\hline 26 & $9+$ & - & $8+$ & $6+$ & - \\
\hline 27 & $9+$ & $8+$ & - & $8+$ & $9+$ \\
\hline 28 & $9+$ & - & - & $8+$ & $8+$ \\
\hline Average & $8.38+$ & $7.14+$ & $8.25+$ & $6.77+$ & $7.83+$ \\
\hline Interquartile & 1.00 & 1.00 & 1.00 & 2.00 & 2.50 \\
\hline
\end{tabular}

Table A2. Consistency check of the experts' answers, Porters' five forces analysis-interquartile range calculation (last line), empty cells (-) define no answers given.

\begin{tabular}{|c|c|c|c|c|c|}
\hline \multirow[b]{2}{*}{ Questionnaires } & \multicolumn{5}{|c|}{ Factors-P5FA } \\
\hline & $\begin{array}{c}\text { Grid } \\
\text { Connection }\end{array}$ & $\begin{array}{l}\text { Utilization of Fossil } \\
\text { Fuels Driven Devices }\end{array}$ & $\begin{array}{l}\text { Energy Efficiency } \\
\text { Improvements }\end{array}$ & $\begin{array}{l}\text { Rational Use } \\
\text { of Energy }\end{array}$ & $\begin{array}{c}\text { Amount of } \\
\text { Competitors }\end{array}$ \\
\hline 1 & $7+$ & $1-$ & $4-$ & $6-$ & - \\
\hline 2 & $8+$ & $2-$ & $4-$ & $5-$ & - \\
\hline 3 & $8+$ & $1-$ & $4-$ & $4-$ & $5-$ \\
\hline 4 & $7+$ & $2-$ & $6-$ & $3-$ & $8-$ \\
\hline 5 & - & $1-$ & $4-$ & - & $9-$ \\
\hline 6 & $7+$ & $3-$ & $6-$ & - & - \\
\hline 7 & $8+$ & $1-$ & $4-$ & $4-$ & $6-$ \\
\hline 8 & $8+$ & $1-$ & $4-$ & $3-$ & - \\
\hline 9 & $7+$ & $2-$ & $2-$ & $3-$ & - \\
\hline 10 & $5+$ & $1-$ & $6-$ & $4-$ & $7-$ \\
\hline 11 & - & $1-$ & $4-$ & $6-$ & $9-$ \\
\hline 12 & $8+$ & - & $4-$ & $5-$ & $7-$ \\
\hline 13 & $8+$ & $3-$ & $4-$ & & $7-$ \\
\hline 14 & $7+$ & $2-$ & $6-$ & $3-$ & $5-$ \\
\hline 15 & $8+$ & $1-$ & $4-$ & $4-$ & $7-$ \\
\hline 16 & - & $1-$ & $6-$ & $4-$ & - \\
\hline 17 & - & $1-$ & $4-$ & $4-$ & - \\
\hline 18 & $8+$ & $1-$ & $4-$ & $3-$ & - \\
\hline 19 & $7+$ & $2-$ & $2-$ & $3-$ & - \\
\hline 20 & $5+$ & - & $6-$ & $4-$ & - \\
\hline 21 & $7+$ & $1-$ & $4-$ & $6-$ & $8-$ \\
\hline 22 & $8+$ & $1-$ & $4-$ & $5-$ & $4-$ \\
\hline 23 & $8+$ & $1-$ & - & $4-$ & - \\
\hline 24 & $7+$ & $2-$ & $6-$ & $3-$ & $7-$ \\
\hline 25 & $8+$ & $1-$ & $4-$ & - & $8-$ \\
\hline 26 & $7+$ & $3-$ & $6-$ & - & - \\
\hline 27 & $8+$ & $1-$ & $4-$ & $4-$ & $7-$ \\
\hline 28 & $8+$ & $1-$ & $6-$ & $3-$ & \\
\hline Average & $7.38+$ & $1.46-$ & $4.52-$ & $4.04-$ & $6.93-$ \\
\hline Interquartile & 1.00 & 1.00 & 2.00 & 2.00 & 2.00 \\
\hline
\end{tabular}


Table A3. Consistency check of the experts' answers, Porters' five forces analysis-interquartile range calculation (last line), empty cells (-) define no answers given.

\begin{tabular}{|c|c|c|c|c|c|}
\hline \multirow[b]{2}{*}{ Questionnaires } & \multicolumn{5}{|c|}{ Factors-P5FA } \\
\hline & $\begin{array}{c}\text { Market } \\
\text { Liberalization }\end{array}$ & $\begin{array}{l}\text { Capital Accessibility } \\
\text { for New Investments }\end{array}$ & $\begin{array}{c}\text { Freedom in } \\
\text { Choosing Supplier }\end{array}$ & $\begin{array}{c}\text { Accessibility } \\
\text { to Information }\end{array}$ & $\begin{array}{c}\text { Easiness to } \\
\text { Switch Supplier }\end{array}$ \\
\hline 1 & $7-$ & - & $9-$ & $10-$ & - \\
\hline 2 & $8-$ & $7+$ & $6-$ & - & $7-$ \\
\hline 3 & $8-$ & $7+$ & $6-$ & $8-$ & $8-$ \\
\hline 4 & $7-$ & $4+$ & $5-$ & $7-$ & $6-$ \\
\hline 5 & $7-$ & $8+$ & $7-$ & $8-$ & - \\
\hline 6 & $7-$ & $6+$ & $7-$ & $10-$ & $7-$ \\
\hline 7 & $8-$ & $9+$ & $8-$ & $5-$ & $8-$ \\
\hline 8 & $8-$ & - & 7- & $7-$ & $7-$ \\
\hline 9 & $7-$ & - & - & - & $7-$ \\
\hline 10 & $7-$ & $7+$ & $7-$ & $6-$ & $5-$ \\
\hline 11 & $7-$ & $8+$ & $8-$ & $6-$ & - \\
\hline 12 & $8-$ & $7+$ & $6-$ & $6-$ & $7-$ \\
\hline 13 & - & $7+$ & $6-$ & - & $8-$ \\
\hline 14 & - & $5+$ & - & $5-$ & $6-$ \\
\hline 15 & $7-$ & $7+$ & $7-$ & $6-$ & $8-$ \\
\hline 16 & $7-$ & - & $7-$ & $7-$ & - \\
\hline 17 & $7-$ & $9+$ & $8-$ & $6-$ & - \\
\hline 18 & $8-$ & - & $7-$ & $8-$ & $7-$ \\
\hline 19 & $7-$ & $8+$ & - & - & $7-$ \\
\hline 20 & $7-$ & - & $7-$ & $6-$ & $4-$ \\
\hline 21 & $7-$ & $9+$ & $8-$ & $7-$ & $7-$ \\
\hline 22 & $7-$ & $7+$ & $6-$ & $5-$ & $7-$ \\
\hline 23 & $8-$ & $7+$ & $6-$ & $8-$ & $8-$ \\
\hline 24 & $7-$ & $7+$ & - & $6-$ & $7-$ \\
\hline 25 & $7-$ & $7+$ & $7-$ & $7-$ & $8-$ \\
\hline 26 & $7-$ & - & $7-$ & $6-$ & $6-$ \\
\hline 27 & $7-$ & $7+$ & $7-$ & $8-$ & $8-$ \\
\hline 28 & - & - & $8-$ & $9-$ & - \\
\hline Average & $7.28-$ & $7.15+$ & $6.96-$ & $6.96-$ & $6.95-$ \\
\hline Interquartile & 1.00 & 1.00 & 1.75 & 2.00 & 1.25 \\
\hline
\end{tabular}

Table A4. Consistency check of the experts' answers, multiple-criteria decision analysis-interquartile range calculation (last line), empty cells (-) define no answers given.

\begin{tabular}{|c|c|c|c|c|}
\hline \multirow[b]{2}{*}{ Questionnaires } & \multicolumn{4}{|c|}{ Goals-MCDA } \\
\hline & $\begin{array}{c}\text { Environmental } \\
\text { Policies }\end{array}$ & $\begin{array}{c}\text { Feasibility in } \\
\text { Changing Supplier }\end{array}$ & Income Max. & Benefit to Cost Max. \\
\hline 1 & $9+$ & $4-$ & - & $3-$ \\
\hline 2 & $8+$ & $5-$ & $8+$ & $4-$ \\
\hline 3 & $8+$ & $4-$ & $7+$ & - \\
\hline 4 & $6+$ & $2-$ & $8+$ & $3-$ \\
\hline 5 & $8+$ & $4-$ & $8+$ & $2-$ \\
\hline 6 & - & $6-$ & $9+$ & $1-$ \\
\hline 7 & $8+$ & $4-$ & $8+$ & $4-$ \\
\hline 8 & - & $3-$ & $10+$ & $3-$ \\
\hline 9 & - & $3-$ & $8+$ & $2-$ \\
\hline 10 & $7+$ & $3-$ & $10+$ & $2-$ \\
\hline 11 & $9+$ & $4-$ & $8+$ & $3-$ \\
\hline 12 & $7+$ & - & $8+$ & $4-$ \\
\hline 13 & $7+$ & $4-$ & $7+$ & - \\
\hline 14 & $6+$ & $2-$ & $8+$ & $3-$ \\
\hline 15 & - & $4-$ & - & $2-$ \\
\hline 16 & - & $6-$ & $7+$ & $1-$ \\
\hline 17 & $9+$ & $4-$ & $8+$ & $4-$ \\
\hline 18 & - & $3-$ & - & $3-$ \\
\hline 19 & $8+$ & $3-$ & $9+$ & $2-$ \\
\hline 20 & - & $3-$ & $10+$ & $2-$ \\
\hline 21 & $8+$ & $4-$ & - & - \\
\hline 22 & - & $5-$ & $8+$ & $4-$ \\
\hline 23 & $9+$ & $4-$ & $10+$ & - \\
\hline
\end{tabular}


Table A4. Cont.

\begin{tabular}{ccccc}
\hline \multirow{2}{*}{ Questionnaires } & \multicolumn{4}{c}{ Goals-MCDA } \\
\cline { 2 - 5 } & $\begin{array}{c}\text { Environmental } \\
\text { Policies }\end{array}$ & $\begin{array}{c}\text { Feasibility in } \\
\text { Changing Supplier }\end{array}$ & Income Max. & Benefit to Cost Max. \\
\hline 24 & $7+$ & $2-$ & $8+$ & $3-$ \\
25 & $8+$ & $4-$ & $9+$ & $2-$ \\
26 & - & - & $9+$ & - \\
27 & $9+$ & $4-$ & - & $4-$ \\
28 & - & $3-$ & $8+$ & $3-$ \\
\hline Average & $7.83+$ & 1.00 & 1.00 & $2.78-$ \\
\hline Interquartile & 2.00 & &
\end{tabular}

Table A5. Consistency check of the experts' answers, multiple-criteria decision analysis-interquartile range calculation (last line), empty cells (-) define no answers given.

\begin{tabular}{|c|c|c|c|c|}
\hline \multirow[b]{2}{*}{ Questionnaires } & \multicolumn{4}{|c|}{ Factors-MCDA } \\
\hline & $\begin{array}{l}\text { Renewable Energy } \\
\text { Production }\end{array}$ & $\begin{array}{l}\text { Fossil Fuels' } \\
\text { Price }\end{array}$ & $\begin{array}{c}\text { Extreme Weather } \\
\text { Events }\end{array}$ & $\begin{array}{l}\text { Social Unacceptance of Higher } \\
\text { Electricity Prices Due to } \\
\text { Incentives/Subsidies }\end{array}$ \\
\hline 1 & $2+$ & $2+$ & $1-$ & $1-$ \\
\hline 2 & $5+$ & - & $1-$ & $1-$ \\
\hline 3 & $4+$ & $4+$ & - & $2-$ \\
\hline 4 & $4+$ & - & $2-$ & $2-$ \\
\hline 5 & $3+$ & $2+$ & $2-$ & $1-$ \\
\hline 6 & $3+$ & - & $2-$ & $1-$ \\
\hline 7 & $5+$ & $2+$ & - & $1-$ \\
\hline 8 & $5+$ & - & $1-$ & $1-$ \\
\hline 9 & $4+$ & $3+$ & - & $1-$ \\
\hline 10 & $4+$ & $3+$ & $1-$ & $3-$ \\
\hline 11 & $2+$ & $3+$ & $1-$ & $1-$ \\
\hline 12 & $5+$ & - & - & $1-$ \\
\hline 13 & $4+$ & $3+$ & $2-$ & $2-$ \\
\hline 14 & $4+$ & - & $1-$ & $2-$ \\
\hline 15 & $3+$ & $3+$ & $1-$ & $1-$ \\
\hline 16 & $3+$ & - & $1-$ & $1-$ \\
\hline 17 & $5+$ & $4+$ & $2-$ & $1-$ \\
\hline 18 & $5+$ & - & $1-$ & $1-$ \\
\hline 19 & $9+$ & $3+$ & $1-$ & $1-$ \\
\hline 20 & $4+$ & $2+$ & $1-$ & $3-$ \\
\hline 21 & $2+$ & $4+$ & $1-$ & $1-$ \\
\hline 22 & $5+$ & - & $2-$ & $1-$ \\
\hline 23 & $5+$ & $3+$ & $2-$ & $2-$ \\
\hline 24 & $4+$ & - & $2-$ & $2-$ \\
\hline 25 & $3+$ & $3+$ & $2-$ & $1-$ \\
\hline 26 & $3+$ & - & $3-$ & $1-$ \\
\hline 27 & $5+$ & $3+$ & $1-$ & $1-$ \\
\hline 28 & $5+$ & - & $1-$ & - \\
\hline Average & $4.11+$ & $2.94+$ & $1.46-$ & $1.37-$ \\
\hline Interquartile & 2.00 & 0.75 & 1.00 & 1.00 \\
\hline
\end{tabular}

Table A6. Consistency check of the experts' answers, multiple-criteria decision analysis-interquartile range calculation (last line), empty cells (-) define no answers given.

\begin{tabular}{ccccc}
\hline \multirow{2}{*}{ Questionnaires } & \multicolumn{4}{c}{ Factors-MCDA } \\
\cline { 2 - 5 } & $\begin{array}{c}\text { Electricity Market } \\
\text { Concentration }\end{array}$ & E-Mobility & $\begin{array}{c}\text { Electricity Market } \\
\text { Liberalization }\end{array}$ & $\begin{array}{c}\text { EU Economy } \\
\text { Growth }\end{array}$ \\
\hline 1 & $5+$ & - & - & $3+$ \\
2 & $4+$ & $1+$ & $4-$ & $4+$ \\
3 & $5+$ & $1+$ & $6-$ & $3+$ \\
4 & $7+$ & $2+$ & $4-$ & $5+$ \\
5 & $4+$ & $1+$ & $4-$ & $4+$ \\
\hline
\end{tabular}


Table A6. Cont.

\begin{tabular}{ccccc}
\hline \multirow{2}{*}{ Questionnaires } & \multicolumn{4}{c}{ Factors-MCDA } \\
\cline { 2 - 5 } & $\begin{array}{c}\text { Electricity Market } \\
\text { Concentration }\end{array}$ & E-Mobility & $\begin{array}{c}\text { Electricity Market } \\
\text { Liberalization }\end{array}$ & $\begin{array}{c}\text { EU Economy } \\
\text { Growth }\end{array}$ \\
\hline 6 & $6+$ & $1+$ & $4-$ & $5+$ \\
7 & - & $1+$ & $7-$ & $4+$ \\
8 & $4+$ & $1+$ & $7-$ & $4+$ \\
9 & - & $1+$ & $6-$ & $2+$ \\
10 & $6+$ & $2+$ & - & $5+$ \\
11 & $4+$ & $1+$ & - & $4+$ \\
12 & $4+$ & $1+$ & $4-$ & $4+$ \\
13 & $4+$ & $1+$ & $4-$ & $4+$ \\
14 & $7+$ & $2+$ & $4-$ & $6+$ \\
15 & $4+$ & $1+$ & - & $4+$ \\
16 & $6+$ & - & $7-$ & $5+$ \\
17 & $4+$ & $1+$ & - & $4+$ \\
18 & $4+$ & $1+$ & $6-$ & $4+$ \\
19 & $2+$ & $2+$ & - & $4+$ \\
20 & $6+$ & $1+$ & - & $4+$ \\
21 & $4+$ & $1+$ & $4-$ & $4+$ \\
22 & $4+$ & $2+$ & $4-$ & - \\
23 & - & $2+$ & $4-$ & $6+$ \\
24 & $7+$ & $1+$ & $4-$ & $4+$ \\
25 & $4+$ & $1+$ & $5-$ & $5+$ \\
26 & $7+$ & $1+$ & - & $3+$ \\
27 & $4+$ & - & $6-$ & - \\
28 & - & $1.24+$ & $4.90-$ & $4.08+$ \\
\hline Average & $4.83+$ & 0.50 & 2.00 & 1.00 \\
\hline Interquartile & 2.00 & & & $4+$ \\
\hline & & $4+$ & - & \\
\hline
\end{tabular}

\section{References}

1. Sánchez de la Nieta, A.A.; González, V.; Contreras, J. Portfolio Decision of Short-Term Electricity Forecasted Prices through Stochastic Programming. Energies 2016, 9, 1069. [CrossRef]

2. Larsen, E.R.; Bunn, D.W. Deregulation in electricity: Understanding strategic and regulatory risk. J. Oper. Res. Soc. 1999, 50, 337-344. [CrossRef]

3. Rothwell, G.S.; Gómez, T. Electricity Economics: Regulation and Deregulation; Wiley-IEEE Press: Hoboken, NJ, USA, 2003; p. 12.

4. Pinson, P.; Chevallier, C.; Kariniotakis, G.N. Trading wind generation from short-term probabilistic forecasts of wind power. IEEE Trans. Power Syst. 2007, 22, 1148-1156. [CrossRef]

5. Guerrero-Mestre, V.; Sánchez de la Nieta, A.A.; Contreras, J.; Catalao, J.P.S. Optimal bidding of a group of wind farms in day ahead markets through an external agent. IEEE Trans. Power Syst. 2016, 31, 2688-2700. [CrossRef]

6. Sánchez de la Nieta, A.A.; Contreras, J.; Munoz, J.I. Optimal coordinated wind-hydro bidding startegies in day-ahead markets. IEEE Trans. Power Syst. 2013, 28, 798-809. [CrossRef]

7. Sánchez de la Nieta, A.A.; Tavares, T.A.M.; Martins, R.F.M. Optimal generic energy storage system offering in day-ahead electricity markets. In Proceedings of the IEEE PowerTech, Eindhoven, The Netherlands, 29 June-2 July 2015.

8. Weron, R. Electricity price forecasting: A review of the state-of-the-art with a look into the future. Int. J. Forecast. 2014, 30, 1030-1081. [CrossRef]

9. Weron, R. Modeling and Forecasting Electricity Loads and Prices: A Statistical Approach; John Wiley \& Sons: Chichester, UK, 2007; p. 403.

10. Changhao, X.; Wang, J.; Karen, M. Short, medium and long term load forecasting model and virtual load forecaster based on radial basis function neural networks. Int. J. Electr. Power Energy Syst. 2010, 32, 743-750.

11. Cheng, C.; Luo, B.; Miao, S.; Wu, X. Mid-Term Electricity Market Clearing Price Forecasting with Sparse Data: A Case in Newly-Reformed Yunnan Electricity Market. Energies 2016, 9, 804. [CrossRef] 
12. Aggarwal, S.K.; Saini, L.M.; Kumar, A. Electricity price forecasting in deregulated markets: A review and evaluation. Int. J. Electr. Power Energy Syst. 2009, 31, 13-22. [CrossRef]

13. Rubin, O.D.; Babcock, B.A. The impact of expansion of wind power capacity and pricing methods on the efficiency of deregulated electricity markets. Energy 2013, 59, 676-688. [CrossRef]

14. Ruibal, C.M.; Mazumdar, M. Forecasting the mean and the variance of electricity prices in deregulated markets. IEEE Trans. Power Syst. 2008, 23, 25-32. [CrossRef]

15. Wood, A.J.; Wollenberg, B.F. Power Generation, Operation and Control; Wiley: New York, NY, USA, 1996.

16. Battle, C.; Barquin, J.A. A strategic production costing model for electricity market price analysis. IEEE Trans. Power Syst. 2005, 20, 67-74. [CrossRef]

17. Kian, A.; Keyhani, A. Stochastic price modeling of electricity in deregulated energy markets. In Proceedings of the 34th Annual Hawaii International Conference on System Sciences, Maui, HI, USA, 6 January 2001; pp. 1-7.

18. Robinson, T.A. Electricity pool prices: A case study in nonlinear time-series modelling. Appl. Econ. 2000, 32, 527-532. [CrossRef]

19. Carpio, J.; Juan, J.; Lòpez, D. Multivariate exponential smoothing and dynamic factor model applied to hourly electricity price analysis. Technometrics 2014, 56, 494-503. [CrossRef]

20. Nogales, F.J.; Contreras, J.; Conejo, A.J.; Epinola, R. Forecasting next-day electricity prices by time series models. IEEE Trans. Power Syst. 2002, 17, 342-348. [CrossRef]

21. Obradovic, Z.; Tomsovic, K. Time series methods for forecasting electricity market pricing. In Proceedings of the IEEE Power Engineering Society Summer Meeting, Edmonton, AB, Canada, 18-22 July 1999; pp. 1264-1265.

22. Cuaresma, J.C.; Hlouskova, J.; Kossmeier, S.; Obersteiner, M. Forecasting electricity spot-prices using linear univariate time-series models. Appl. Energy 2004, 77, 87-106. [CrossRef]

23. Conejo, A.J.; Plazas, M.A.; Espinola, R.; Molina, A.B. Day-ahead electricity price forecasting using the Wavelet Transform and ARIMA Models. IEEE Trans. Power Syst. 2005, 20, 1035-1042. [CrossRef]

24. Zhang, J.; Tan, Z. Day-ahead electricity price forecasting using WT, CLSSVM and EGARCH model. Int. J. Electr. Power Energy Syst. 2013, 45, 362-368. [CrossRef]

25. Contreras, J.; Espinola, R.; Nogales, F.J.; Conejo, A.J. ARIMA models to predict next-day electricity prices. IEEE Trans. Power Syst. 2003, 18, 1014-1020. [CrossRef]

26. Jakaša, T.; Andročec, I.; Sprčić, P. Electricity price forecasting-ARIMA model approach. In Proceedings of the 8th International Conference on the European Energy Market (EEM), Zagreb, Croatia, 25-27 May 2011; pp. 222-225.

27. Xie, M.; Sandels, C.; Zhu, K. A seasonal ARIMA model with exogenous variables for elspot electricity prices in Sweden. In Proceedings of the 10th International Conference on the European Energy Market (EEM), Stockholm, Sweden, 1-4 May 2013; pp. 27-31.

28. Szkuta, B.R.; Sanabria, L.A.; Dillon, T.S. Electricity price short-term forecasting using artificial neural networks. IEEE Trans. Power Syst. 1999, 14, 851-857. [CrossRef]

29. Keles, D.; Scelle, J.; Paraschiv, F.; Fichtner, W. Extended forecast methods for day-ahead electricity spot prices applying artificial neural networks. Appl. Energy 2016, 162, 218-230. [CrossRef]

30. Shrivastava, N.A.; Khosravi, A.; Panigrahi, B.K. Prediction interval estimation of electricity prices using PSO-Tuned Support Vector Machines. IEEE Trans. Ind. Inf. 2015, 11, 322-331. [CrossRef]

31. Papadimitriou, T.; Gogas, P.; Stathakis, E. Forecasting energy markets using support vector machines. Energy Econ. 2014, 44, 135-142. [CrossRef]

32. Zhao, J.H.; Dong, Z.; Li, X.; Wong, K. A framework for electricity price spike analysis with advanced data mining methods. IEEE Trans. Power Syst. 2007, 22, 376-385. [CrossRef]

33. Huang, D.; Zareipour, H.; Rosehartet, W.D.; Amjady, N. Data mining for electricity price classification and the application to demand-side management. IEEE Trans. Smart Grid 2012, 3, 808-817. [CrossRef]

34. Tan, Z.F.; Zhang, J.L.; Wang, J.H.; Xu, J. Day-ahead electricity price forecasting using wavelet transform combined with ARIMA and GARCH models. Appl. Energy 2010, 87, 3606-3610. [CrossRef]

35. Gonzalez, V.; Contreras, J.; Bunn, D.W. Forecasting power prices using a hybrid Fundamental-Econometric model. IEEE Trans. Power Syst. 2012, 27, 363-372. [CrossRef]

36. Cerjan, M.; Matijaš, M.; Delimar, M. Dynamic hybrid model for short-term electricity price forecasting. Energies 2014, 7, 3304-3318. [CrossRef] 
37. Garcia, R.; Contreras, C.J.; Van Akkeren, M.; Garcia, J.B.C. A GARCH forecasting model to predict day-ahead electricity prices. IEEE Trans. Power Syst. 2005, 20, 867-874. [CrossRef]

38. Bowden, N.; Payne, J.E. Short term forecasting of electricity prices for MISO hubs: Evidence from ARIMA-EGARCH models. Energy Econ. 2008, 30, 3186-3197. [CrossRef]

39. Catalão, J.P.D.S.; Mariano, S.J.P.S.; Mendes, V.M.F.; Ferreira, L.A.F.M. Short-term electricity prices forecasting in a competitive market: A neural network approach. Electr. Power Syst. Res. 2007, 77, 1297-1304. [CrossRef]

40. Kyoung-jae, K. Financial time series forecasting using support vector machines. Neurocomputing 2003, 55, 307-319.

41. Galli, R. The relationship between energy intensity and income levels: Forecasting long term energy demand in Asian emerging countries. Energy J. 1998, 19, 85-105. [CrossRef]

42. Pindyck, R.S.; Pindyck, R.S. The long-run evolution of energy prices. Energy J. 1999, 20, 1-27. [CrossRef]

43. Koritarov, V.S. Real-world market representation with agents. IEEE Power Energy Mag. 2004, 2, 39-46. [CrossRef]

44. Yan, X.; Chowdhury, N.A. Mid-term electricity market clearing price forecasting: A hybrid LSSVM and ARMAX approach. Int. J. Electr. Power Energy Syst. 2013, 53, 20-26. [CrossRef]

45. Torghaban, S.S.; Zareipour, H.; Tuan, L.A. Medium-term electricity market price forecasting: A data-driven approach. In Proceedings of the 2010 North American Power Symposium (NAPS 2010), Arlington, TX, USA, 26-28 September 2010.

46. Torghaban, S.S.; Motamedi, A.; Zareipour, H.; Tuan, L.A. Medium-term electricity price forecasting. In Proceedings of the 2012 North American Power Symposium (NAPS 2012), Champaign, IL, USA, 9-11 September 2012; pp. 1-8.

47. Bello, A.; Renses, J.; Munoz, A. Medium-term probabilistic forecasting of extremely low prices in electricity markets: Application to the Spanish case. Energies 2016, 9, 193. [CrossRef]

48. Yan, X.; Chowdhury, N.A. Mid-term electricity market clearing price forecasting: A multiple SVM approach. Int. J. Electr. Power Energy Syst. 2014, 58, 206-214. [CrossRef]

49. Sailor, D.J.; Pavlova, A. Air conditioning market saturation and long-term response of residential cooling energy demand to climate change. Energy 2003, 28, 941-951. [CrossRef]

50. Suganthi, L.; Anand, A.S. Energy models for demand forecasting-A review. Renew. Sustain. Energy Rev. 2012, 16, 1223-1240. [CrossRef]

51. Lijesen, M.G. The real-time price elasticity of electricity. Energy Econ. 2007, 29, 249-258. [CrossRef]

52. Bianco, V.; Manca, O.; Nardini, S. Electricity consumption forecasting in Italy using linear regression models. Energy 2009, 34, 1413-1421. [CrossRef]

53. Kumar, U.; Jain, V.K. Time series models (Grey-Markov, Grey Model with rolling mechanism and singular spectrum analysis) to forecast energy consumption in India. Energy 2010, 35, 1709-1716. [CrossRef]

54. Hyndman, R.J.; Fan, S. Density forecasting for long-term peak electricity demand. IEEE Trans. Power Syst. 2010, 25, 1142-1153. [CrossRef]

55. Kok, M.; Lootsma, F.A. Pairwise-comparison methods in multiple objective programming, with applications in a long-term energy-planning model. Eur. J. Oper. Res. 1985, 22, 44-55. [CrossRef]

56. Porter, M.E. The Five Competitive Forces that Shape Strategy. Harv. Bus. Rev. 2008, 86, $25-40$.

57. Pezzutto, S. Analysis of the Space Heating and Cooling Market in Europe. Ph.D. Thesis, University of Natural Resources and Life Sciences, Vienna, Austria, 2014.

58. Porter, E.M. How competitive forces shape industry. Harv. Bus. Rev. 1979, 57, 137-145.

59. Pezzutto, S.; Fazeli, R.; De Felice, M.; Sparber, W. Future development of the air-conditioning market in Europe: An outlook until 2020. Wiley Interdiscip. Rev. Energy Environ. 2016, 5, 649-669. [CrossRef]

60. New Energy Externalities Developments for Sustainability. Available online: https://cordis.europa.eu/ result/rcn/49560_en.html (accessed on 26 February 2018).

61. Some Initial Methodological Considerations in the Development and Design of Delphi Surveys. Available online: https:/ / orca.cf.ac.uk/9949/1/Initial\%20methodological\%20considerations\%20in\%20the\% 20development\%20and\%20design\%20of\%20Delphi\%20surveys.pdf (accessed on 20 February 2018).

62. Malczweski, J. GIS and Multicriteria Decision Analysis; John Wiley \& Sons: New York, NY, USA, 1999 ; p. 69.

63. Percentiles. Available online: http://cnx.org/content/m10805/latest/ (accessed on 22 January 2018).

64. Ehrgott, M.; Figueria, J.R.; Greco, S. Trends in Multiple Criteria Decision Analysis; Springer: Boston, MA, USA, 2010; p. 13. 
65. Rao, K.D. Multi-criteria spatial decision analysis for forecasting urban water requirements: A case study of Dehradun city, India. Landsc. Urban Plan. 2005, 71, 163-174.

66. Onder, E.; Hepsen, A. Combining Time Series Analysis and Multi Criteria Decision Making Techniques for Forecasting Financial Performance of Banks in Turkey. Int. J. Latest Trends Financ. Econ. Sci. 2013, 3, 530-550.

67. Euphemia Public Description. Available online: http://www.belpex.be/wp-content/uploads/Euphemiapublic-description-Nov-2013.pdf (accessed on 18 May 2018).

68. Cosmos Public Description. Available online: http://www.belpex.be/wp-content/uploads/COSMOS_ public_description.pdf (accessed on 19 May 2018).

69. EU Emissions Trading System. Available online: https://ec.europa.eu/clima/policies/ets_en (accessed on 18 May 2018).

70. 2020 Climate \& Energy Package. Available online: https://ec.europa.eu/clima/policies/strategies/2020_en (accessed on 18 May 2018).

71. Directive of the European Parliament and of the Council on Common Rules for the Internal Market in Electricity (Recast). Available online: https:/ / ec.europa.eu/energy/sites/ener/files/documents/1_en_act_ part1_v7_864.pdf (accessed on 18 May 2018).

72. Saaty, T.L. Decision making with the analytic hierarchy process. Int. J. Serv. Sci. 2008, 1, 83-98. [CrossRef]

73. Haas, R.; Meixner, O. An Illustrated Guide to the Analytic Hierarchy Process; University of Natural Resources and Applied Life Sciences: Vienna, Austria, 2013.

74. The Analytical Hierarchy Process: A New Tool for Complex Decision-Making in Public Health. Available online: https://medepi.files.wordpress.com/2012/02/phprep-summit-2012-ahp2.pdf (accessed on 10 January 2018).

75. Global Marketing. Available online: http://proz-x.com/stephanlangdon/Library/USCore/Hollensen. Global_Marketing.pdf (accessed on 6 January 2018).

76. Trends in Extreme Weather Events in Europe: Implications for National and European Union Adaptation Strategies. Available online: https:/ / easac.eu/fileadmin/PDF_s/reports_statements/Extreme_Weather / EASAC_report_Extreme_Weather_in_Europe_Nov13.pdf (accessed on 1 March 2018).

77. European Environment Agency Overview of Electricity Production and Use in Europe. Available online: https: / / www.eea.europa.eu/data-and-maps/indicators/overview-of-the-electricity-production1/assessment (accessed on 2 October 2017).

78. Market Analysis. Available online: https://ec.europa.eu/energy/en/data-analysis/market-analysis (accessed on 2 January 2018).

79. Future Electricity Prices. Available online: https://www.ecn.nl/publicaties /PdfFetch.aspx?nr=ECN-E--08044 (accessed on 28 March 2018).

80. Long-Term Market Analysis, the Nordic Region and Europe 2016-2040. Available online: http:/ / www.statnett.no/Documents /Nyheter_og_media/Nyhetsarkiv/2016/Long-term\%20Market\% 20Analysis\%20The\%20Nordic\%20Region\%20and\%20Europe\%202016-2040.pdf (accessed on 2 March 2018).

(C) 2018 by the authors. Licensee MDPI, Basel, Switzerland. This article is an open access article distributed under the terms and conditions of the Creative Commons Attribution (CC BY) license (http://creativecommons.org/licenses/by/4.0/). 